Arabs and Young Turks 



\section{Arabs and Young Turks}

Ottomanism, Arabism, and Islamism in the Ottoman Empire, I9O8-I9I8

Hasan Kayalı

UNIVERSITY OF CALIFORNIA PRESS

Berkeley / Los Angeles / London 
University of California Press

Berkeley and Los Angeles, California

University of California Press, Ltd.

London, England

(C) 1997 by the Regents of the University of California

Some parts of this book have been published previously in somewhat different form. Parts of various chapters: "Greater Syria under Ottoman Constitutional Rule: Ottomanism, Arabism, and Regionalism", in The Syrian Land in the I8th and Igth Century, ed. Thomas Philipp, 27-4I (Stuttgart: Franz Steiner Verlag, 1992).

Part of chapter 5: "A Note on Railway Construction Schemes in the Hijaz During the Second Constitutional Period of the Ottoman Empire", Arab Historical Review for Ottoman Studies (Tunis), no. 5-6 (1992): 39-43.

Library of Congress Cataloging-in-Publication Data

Kayal, Hasan.

Arabs and Young Turks : Ottomanism, Arabism, and Islamism in the Ottoman Empire, 1908-1918 / Hasan Kayal.

p. $\quad \mathrm{cm}$.

Includes bibliographical references and index.

ISBN 0-520-20444-I (alk. paper). - ISBN o-\$20-20446-8 (pbk. : alk. paper)

r. Arab countries-Foreign relations-Turkey. 2. Turkey-Foreign relations-Arab countries. 3. Turkey-Politics and government-1909-1918. I. Title.

DS63.2.T8K $39 \quad 1997$

$327.56017^{\prime} 4927-$ dc2O $^{2}$

96-II474

Manufactured in the United States of America

$\begin{array}{lllllllll}9 & 8 & 7 & 6 & 5 & 4 & 3 & 2 & 1\end{array}$

The paper used in this publication meets the minimum requirements of American National Standard for Information Sciences-Permanence of Paper for Printed Library Materials, ANSI Z39.48-1984. 
To Ayşe, Murat, and Nihal 
